\title{
INVESTIGATING INDONESIAN EFL STUDENTS' RESPONSES OF THE IMPLEMENTATION OF INTERCULTURAL LANGUAGE LEARNING
}

\author{
Fauzi Miftakh \\ Department of English Education, Faculty of Teacher Training and Education \\ University of Singaperbangsa Karawang, Indonesia \\ E-mail: miftakh.fauzi@yahoo.co.id
}

\begin{abstract}
APA Citation: Miftakh, F. (2015). Investigating Indonesian EFL students' responses of the implementation of intercultural language learning. English Review: Journal of English Education, 4(1), 66-74
\end{abstract}

Received: 06-01-2015

Accepted: 07-03-2015

Published: 01-12-2015

\begin{abstract}
:
This study aimed at discovering the students' responses to the implementation of intercultural language learning at the sixth semester students of the English Education Department, University of Singaperbangsa Karawang, Indonesia. The focus of the study was on 1) the students' general attitudes toward the course, 2) the students' attitudes toward the implementation of teaching and learning and 3) the students' responsibility as an intercultural person. This study was designed as a descriptive qualitative study that involved 31 participants. The data were collected through questionnaire and interviews. Based on the findings, the students gave positive responses to the implementation of intercultural language learning and they showed a greater interest in participating in the course. The intercultural language learning also proved that the students were given the opportunity to become intercultural speakers either during the teaching and learning process or in their daily life. Finally, it recommends that the intercultural approach should be implemented by other English teachers in any subject and at all levels of students.

Keywords: interculural language learning, intercultural competence, English as a foreign language.
\end{abstract}

\section{INTRODUCTION}

Teaching culture has been commonly known in English language teaching. However, in learning English at school and university, there is not necessarily a guarantee to implement an intercultural approach that the cultural aspects of the target language are also studied, or at least inserted in each lesson including in the materials. Damen (1987) states that the curriculum of ESL (English as a second language) and EFL (English as a foreign language), or any language classroom are not usually involved in the cultural guidance of the stated curriculum. Byram (as cited in Liddicoat and Kohler, 2012) states that cultural understanding has been included in such programs. It has typically been separated from the learning of language. In the current Indonesian Education policy, the government tends to consider that foreign languages will diminish the people's sense of nationality (Sukarno, 2012). It seems that the government assumes that the foreign culture in the English language teaching possibly can give bad effects to the Indonesian culture. Tantri (2013) also adds that many schools are reluctant to accept English culture in teaching English at the school although it has positive attitudes 
ENGLISH REVIEW: Journal of English Education Vol. 4, Issue 1, December 2015
ISSN 2301-7554

https://journal.uniku.ac.id/index.php/ERJEE to the need and necessity of teaching and learning of the English language.

Another crucial problem is derived from the English teachers themselves who do not quite understand the concept of the target language culture (Rodliyah \& Muniroh, 2012). They usually do not know how to convey the cultural aspect of target language in teaching English. This misunderstanding is a complex issue because a teacher is a primary source of information and a mediator in the classroom. In addition, Ho's study (2009) suggests a shift from a traditional to intercultural stance in EFL classrooms that contribute to teachers' professional development. Thus, the awareness of the inextricable relationship between language and culture and teaching culture as an integral component of language teaching can be more improved by English teachers. Therefore, teachers should understand the cultural knowledge and likewise they also understand the knowledge of English language in general.

As stated by $\mathrm{Gu}$ (2005), intercultural understanding enables teachers to preserve an open yet critical mind to look for differences and similarities in pursuit of appropriate pedagogy. Ideally, a non-native English teacher who has lived or studied in English speaking countries or any other country will be easier to understand the culture of the target language because they have communicated directly with native speakers. However, it is not the reason to not understand the target culture because through the advancement of technology and the availability of many books they could learn the cultural differences by themselves. As stated by Byram et al. (2002), a teacher does not need to know everything about the target culture, but his role is to help learners to understand how intercultural interaction takes place. However, to implement the method, a teacher must understand the basic concept of intercultural language learning itself as well as incorporate culture and knowledge of the target language.

Derived from the background of the study above, this study attempted to investigate some issues of the students' response of the implementation of intercultural language learning. The research questions are then formulated as 1) what are the students' general attitudes toward the course, 2) what are the students' attitudes toward the implementation of teaching and learning and 3) how does the intercultural language learning affect them to be an intercultural person?

To discuss intercultural language learning, firstly we have to know the difference between cultural and intercultural learning. There is a main difference between a cultural and an intercultural perspective as stated by Liddicoat (2005c) that a cultural perspective emphasizes the culture of the other and leaves that culture external to the learner, whereas an intercultural perspective emphasizes the learners' own cultures as a fundamental part of engaging with a new culture. Lucas (2003) and Kim \& Goldstein (2005) add that intercultural communication involves people from different cultural backgrounds interact with each other that includes language by encompassing the background of the participants, stereotypes or prejudices they may hold of the other cultural group.

In language teaching, Liddicoat (2005b) explains that a cultural perspective implies the development of knowledge about a culture, which remains external to the learner and is not 
intended to confront or transform the learner's existing identity, practices, values, attitudes, beliefs, and world view. He clarifies that an intercultural perspective implies the transformational engagement of the learner in the act of learning. The goal of learning is to 'decenter' learners from their preexisting assumptions and practices and to develop an intercultural identity through engagement with an additional culture.

The outcome of intercultural learning is intercultural competence, a long term change of a person's knowledge (cognition), attitudes (emotions), and skills (behaviour) to enable positive and effective interaction with members of other cultures both abroad and at home (Bennett, in Otten, 2003). The concept has a strong correlation to the intercultural communicative competence that was formulated by Byram and Zarate (1994) as cited in Liddicoat et al., (2003). Guilherme (2002) cited in Corbett (2003), stated that intercultural communicative competence is the ultimate goal of an intercultural approach to language education, and not so much 'native speaker competence'. Intercultural communicative competence includes the ability to understand the language and behavior of the target community, and explain it to the members of the 'home' community and vice versa. These competences lead the students to be intercultural speakers or mediators that are defined as someone who are able to deal with complexity and multiple identities and to avoid the stereotyping which accompanies perceiving someone through a single identity (Byram et al, 2002; Bredella, 2003)

Furthermore, an important dimension of intercultural language teaching is that it is possible to understand another culture only by comparing it with one's own (Champagne \& Bourdages, 2000). As a result, in order to learn about another culture we need to learn about our own culture at the same time by comparing our own culture with the target culture. In order to achieve this, intercultural language teaching argues for a set of principles for developing an overall approach to teaching culture within language (Crozet \& Liddicoat, 2000). The principles include:

1. Culture is integrated into language macroskills not a separate macroskill and the culture needs to be taught simultaneously with and integrated into language teaching;

2. Culture is taught from the beginning of language learning and is not delayed until learners have acquired some of the language;

3. The bilingual speaker is the norm and learners are expected to become competent users of a complex linguistic repertoire involving multiple languages;

4. Language acquisition involves intercultural exploration: it is an active interaction with other attitudes, beliefs, and behaviors, not a passive reception of facts; and

5. Culture learning primarily involves learning how to discover new information about the culture while engaging with the culture.

In addition, Liddicoat et al. (2003) and Liddicoat and Scarino (2013) develop a set of principles of intercultural language learning. The principles consist of five general principles of learning, which are also fundamental to teaching and learning languages. These principles are intended to guide the curriculum design and classroom interaction to promote effective intercultural language learning. The principles consist of 1) Active construction; this principle generally 
involves the purposeful and active construction of knowledge within a sociocultural context of use in learning activities. Learning also involves active engagement in interpreting and creating meaning in interaction with others, and continually reflecting on one's self and others in communication and meaningmaking in variable contexts, 2) Making connection; learning is based on previous knowledge and requires challenges to initial conceptions that learners bring. It emphasizes to the ability to relate and view the connections between cultures. It occurs when relevant bridges are built between home language / culture and target language /culture, with existing knowledge positioned in light of new input, 3) Social Interaction; recognizing that learning and communication are social and interactive that means we communicate with people around us by using language that constructs an interaction. There are many ways of communications between different people, including their age, status, relationship, and etcetera, 4) Reflection; it is fundamental to any teaching and learning process that focuses on interpretation. It involves learners having response and doing reflection of other cultures as well as concepts such as diversity, identity, experiences without stereotyping, and 5) Responsibility; a learner should be responsible. In the intercultural language learning, responsibility is a principle that recognizes that learning depends on the learner's attitudes, dispositions, and values, developed over time.

\section{METHOD}

This study employed a descriptive qualitative research design. Descriptive study is designed to describe a picture of situations, characteristics of groups and phenomena as it naturally happens. (Fraenkel \& Wallen, 1993; Ary et al., 2002). The data collection techniques used were questionnaires and interviews where the data analysis was done qualitatively without statistical analysis. This study was undertaken at a tertiary level of the English Education Department at a state university in West Java. The subject taken was students at the $6^{\text {th }}$ semester level who had taken cross-cultural understanding subject. In addition, the participants involved one single class out of 9 classes in the $6^{\text {th }}$ semester students of the English Education Department that consists of 31 students.

\section{RESULTS AND DISCUSSION}

The discussion of the students' responses to the implementation of intercultural language learning is divided into three parts. The first part is the students' general attitudes toward the course, the second is the students' attitudes toward the implementation of teaching and learning and the third is the students' responsibility as an intercultural person. The questionnaire consists of 11 numbers. The finding of the questionnaire can be seen in the table below.

Table: The summary of questionnaire of the students' responses

\begin{tabular}{|c|c|c|c|c|c|}
\hline No & Statement & $\begin{array}{c}\text { Very } \\
\text { Disagree }\end{array}$ & Disagree & Agree & $\begin{array}{l}\text { Very } \\
\text { Agree }\end{array}$ \\
\hline 1 & $\begin{array}{l}\text { Learning English with Intercultural approach is } \\
\text { interesting. }\end{array}$ & - & $3.22 \%$ & $77.41 \%$ & $19.35 \%$ \\
\hline 2 & $\begin{array}{l}\text { I like learning English both the language and } \\
\text { culture. }\end{array}$ & - & $6.45 \%$ & $64.52 \%$ & $29.03 \%$ \\
\hline
\end{tabular}




\begin{tabular}{|c|c|c|c|c|c|}
\hline 3 & $\begin{array}{l}\text { My understanding about English language and its } \\
\text { culture is improved. }\end{array}$ & - & $3.22 \%$ & $74.19 \%$ & $22.58 \%$ \\
\hline 4 & $\begin{array}{l}\text { Learning culture means learning the habit, } \\
\text { tradition, values, norms etc. }\end{array}$ & - & $3.22 \%$ & $61.29 \%$ & $35.48 \%$ \\
\hline 5 & $\begin{array}{l}\text { I am more active to give my ideas and opinion in } \\
\text { the discussion in this course. }\end{array}$ & - & $3.22 \%$ & $61.29 \%$ & $35.48 \%$ \\
\hline 6 & $\begin{array}{l}\text { I am more critical to see a case or problem among } \\
\text { cultures at the classroom. }\end{array}$ & & $3.22 \%$ & $48.38 \%$ & $45.16 \%$ \\
\hline 7 & $\begin{array}{l}\text { I like when the teacher supported and stimulated } \\
\text { us to think about new knowledge of English } \\
\text { language and culture }\end{array}$ & - & $9.77 \%$ & $70.96 \%$ & $22.58 \%$ \\
\hline 8 & $\begin{array}{l}\text { I like when I could have an interactive talk and } \\
\text { discussion both with students and teachers about a } \\
\text { case among cultures. }\end{array}$ & - & $3.22 \%$ & $80.64 \%$ & $16.12 \%$ \\
\hline 9 & $\begin{array}{l}\text { I like when teacher guided conversation to include } \\
\text { students' views, judgments with students. }\end{array}$ & - & $6.45 \%$ & $70.96 \%$ & $19.35 \%$ \\
\hline 10 & $\begin{array}{l}\text { I should be responsible to be an intercultural } \\
\text { person, by not judging a culture wrong and } \\
\text { believing my culture as the best one. }\end{array}$ & - & - & $77.41 \%$ & $22.58 \%$ \\
\hline 11 & $\begin{array}{l}\text { I think that I should appreciate any differences in } \\
\text { our society and view it positively. }\end{array}$ & - & $3.22 \%$ & $80.64 \%$ & $16.12 \%$ \\
\hline & Percentage of responses & $0 \%$ & $4.17 \%$ & $69.97 \%$ & $25.85 \%$ \\
\hline
\end{tabular}

The students' attitudes toward the course

The data obtained from the questionnaire and interview with students show various responses. There are three points that can be highlighted based on the finding that is: 1) the students' interest in learning English and its culture, 2) the students' understanding of English and its culture, and 3) the students' problems in learning English with intercultural language learning. The first, the students showed a great interest in learning English with an intercultural approach.

They admitted that they enjoyed the course and participated in every meeting. It can be seen in the data from questionnaire that shows most students $(77.41 \%)$ are very interested and the other $19: 35 \%$ of students enjoy learning in the classroom. They also said that they liked to not only learn the language, but also to learn the culture. They said that learning of English and its culture is interesting, so they could find new knowledge about culture. It is also supported by the students' statements during interview, such as from the student 1 and student 2 . Student 1 said that "I very enjoyed this course because I learned a culture that in fact we also learned the language, so they are interrelated, and it's very important to be studied". While the student 2 mentioned that "I enjoyed because I did not study in a formal setting. I also could improve some of my skills". As mentioned by Brown (1994) language is part of a culture and culture is part of the language. Furthermore, student 2 mentioned that he enjoyed because he experienced an informal setting of teaching and learning. It is known that in the principle of intercultural language learning, students should be engaged in an interactive discussion and conversation (Liddicoat \& Scarino, 2013; Corbett, 2003)

Additionally, the second, the students claimed that their understanding about English and its culture has improved. They understand that there is correlation between language and culture, so they think that 
ENGLISH REVIEW: Journal of English Education Vol. 4, Issue 1, December 2015
ISSN 2301-7554

https://journal.uniku.ac.id/index.php/ERJEE they should learn a language and its culture. Based on the result of the questionnaire, a total of $74.19 \%$ of students admitted that intercultural language learning improves their understanding towards English and its culture while the other $22: 58 \%$ of students claimed that they have improved their understanding. The students' statements from interview also support the data from the questionnaire. For example, the student 2 said that "I personally know both the language and its culture. From the culture, I know new knowledge that some of foreign cultures are similar to our culture". While the student 6 said "I more understand the culture itself, because there were not too many language differences that were taught, although there is interconnected between language and culture". However, this students' understanding of the relationship between language and culture cannot be stated as an accurate and comprehensive understanding because the information is only taken from the interview. For a more comprehensive understanding, the students are needed to give a test and evaluation through their personal attitudes and behaviors.

The third, although most students enjoy learning English with intercultural language learning, they still have some problems in participating in the course. The students admitted that they found difficulties in expressing their opinion in a discussion. As the answer from student 4 in the interview, who said that the discussion was too often, so sometimes he was bored, although he actually like discussion. It is known that in every meeting, there was always discussion that involved all students and the teacher. The students sometimes canceled to convey their opinions because they could not speak English fluently. Some students said that they were still afraid of making mistakes, so when they finally speak, they prefer to speak in Indonesian. This problem, actually, has been anticipated by the teacher by always encouraging them to speak and share their opinions.

Therefore, it becomes a challenge for the teacher to make sure that every student is able to interact and communicate in the classroom. It is known that one of the principle of intercultural language learning is social interaction (Liddicoat \& Scarino, 2013) when the students should get involved in conversation that discuss about cultures.

The students' attitudes toward the implementation of the teaching and learning

This section is more emphasized to two points that is the students' competence and their perspectives of the teacher related to the principles of intercultural language learning. Based on the data taken from the questionnaire and interview, the students claimed that they have positive progress as well as good improvement of learning.

The first, the students stated that they become more active in expressing their opinions and perspectives in a discussion or conversation. They also said that they think more critically when seeing a case or problem among cultures in the classroom. Their critical thinking can be seen from activities, especially in discussions where they could work with the other students in a group. They also listened to the other opinions and gave response as well as providing solutions. As stated in data from questionnaire, $61.29 \%$ of students and $35.48 \%$ of students extremely agree that they became more active to argue and give their opinions in the class discussions. Besides, as many as $48.38 \%$ and $45.16 \%$ of the students also found 
intercultural language learning to make them think more critically to see cases, or the differences among cultures. The most important thing is that they do not easily judge a problem found as a bad or good, rather they view it from the other people's view, so they can act and speak properly. Therefore, it indicates that the students have critically seen a thing from a different point of view. It is, of course, in line with the principle of intercultural language learning (Liddicoat et al, 2003; Liddicoat \& Scarino, 2013) that the students should have critical thinking toward the differences of language and culture. Regarding the students' active participation in the classroom, Moloney and Harbon (2010) also found that in intercultural language learning classroom, the students used target language in social interaction to express opinions, problem-solving, use highorder thinking. Students were also actively tested and engaged their prior knowledge, that is, their existing cultural knowledge and expectations. This is in line with the data found in the questionnaire where the students claimed that they have developed to perform interactive participation as well as to be an independent person by using their existing or prior knowledge about the target culture that they discussed in every meeting.

The students' responsibility as intercultural persons

This last section discusses the students' responsibility as intercultural persons. It means that they are assumed have followed all meetings of the courses and they have received knowledge related to the principle of intercultural language learning. This responsibility is how their attitudes and behavior toward diversity and difference are implemented not only in the classroom but also in their environment. Therefore, the responsibility is also the students' prolonged engagement as responsible persons in their environment in the future.

There are two important points that are highlighted in this section, namely the students' responsibility to value the other cultures and the students' perspective towards the diversity and difference among cultures. In general, the students claimed that they have become intercultural persons and they do not judge other cultures are worse than their own cultures. They also believed that they more appreciate the diversity and differences in their environment. They think that the diversity is a good thing as long as it gives a positive impact to people and it does not disrupt the harmony of people. As stated in data questionnaire, a total of $77.41 \%$ of students believed that they have been being intercultural persons, and $80.64 \%$ of students also believed that they can appreciate the diversity and differences in society regardless of it as something wrong.

On the other hand, students' statements in the data interview also support that they have been responsible as intercultural persons. For example, student 1 said that "every opinion should be respected, although it may be different from mine", and a statement from student 3 that is "after following this course I became increasingly aware that we should be able to see someone's opinion from different views. We do not become a selfish person". In conclusion, the students' responses above show that the teaching and learning that they have participated have met the objective of the intercultural language learning that creates them to be intercultural persons and intercultural speakers or mediators, as mentioned by Byram et al (2012), 
ENGLISH REVIEW: Journal of English Education Vol. 4, Issue 1, December 2015
ISSN 2301-7554

https://journal.uniku.ac.id/index.php/ERJEE
Corbett (2003) and Liddicoat and Scarino (2013). It will create studentswho are able to deal withcomplexity and multiple identities and to avoid the stereotyping whichis accompanied by perceiving someone through a single identity.

\section{CONCLUSION}

Based on the results, the conclusion can be drawn as 1) the students' general attitudes toward the course. The students showed a greater interest in participating in the course. They were also impressed to some activities in the classroom, including teacher's role in the discussion. They said that learning English and its culture was interesting, and they experienced interesting activities to find new knowledge about language and culture. However, they still have some problems in participating in the course. They admitted that they found difficulties in expressing their opinion in a discussion. It had been anticipated by the teacher by always encouraging them to speak and share their opinions. 2) The students' attitudes toward the implementation of teaching and learning. The students had positive progress as well as good improvement of learning.

They appreciated the teacher who had given greater involvement and guidance during the teaching and learning. They also enjoyed the activities done by the teacher in the classroom. They mentioned that they became more active and critical in expressing their opinions and perspectives in a discussion or conversation to see some cases and differences among cultures. The most important thing is that they do not easily judge a problem found as a bad or good, rather they view it from the other people's view, so they can act and speak properly. 3) The effect of intercultural language learning to students as an intercultural person. The students claimed that they had become intercultural persons where they did not see and easily judged a cultural difference as a bad thing rather seeing it in different point of views either during the teaching and learning process or in their environment in the future.

\section{REFERENCES}

Ary, D., Jacobs, L.C., Razavieh, A. (2002). Introduction to research in education. Michigan: Wadsworth, Thompson Learning.

Bredella, L. (2003). For a flexible model of intercultural understanding. In G. Alred., M. Byram., and M. Fleming. (Eds), Intercultural experience and education (p. 31-49). Clevedon: Multilingual Matters.

Brown, H. D. (1994). Principles of language learning and teaching. Englewood Cliffs, New Jersey: Prentice Hall Regents.

Byram, M., Gribkova, B., \& Starkey, H. (2002). Developing the intercultural dimension in language teaching: A practical introduction for teachers. Strasbourg: Council of Europe

Champagne, C. \& Bourdages, J.S. (2000). Didactiser la culture par la comparaison réflective. International Review of Applied Linguistics, 38, 279-287.

Corbett, J. (2003). An intercultural approach to English language teaching. Clevendon: Multilingual Matters.

Crozet, C., \& Liddicoat, A.J. (2000). Teaching culture as an integrated part of language: Implications for the aims, approaches and pedagogies of language teaching. In A.J. Liddicoat \& C. Crozet (eds), Teaching Languages, Teaching Cultures. Melbourne: Language Australia.

Damen, L. (1987). Culture learning: The fifth dimension in the language classroom. Massachusetts: Addison-Wesley Publishing Company, Inc.

Fraenkel, R. J. \& Wallen, E. N. (1993). How to design and evaluate research in education. New York: Mcgraw-Hill 
$\mathrm{Gu}, \mathrm{Q}$. (2005). Intercultural experience and teacher professional development. Regional Language Centre Journal, 36(1), $5-22$.

Ho, S.T.K. (2009). Addressing culture in EFL classrooms: The challenge of shifting from a traditional to an intercultural stance. Electronic Journal of Foreign Language Teaching, 6(1), 63-76.

Kim, R. I. \& Goldstein, S. B. (2005). Intercultural attitudes predict favorable study abroad expectations of U.S. college students. Journal of Studies in International Education, 9(3), 265-278.

Liddicoat, A. J. (2005b). Teaching languages for intercultural communication. In D. Cunningham and A. Hatoss (Eds), An international perspective on language policies, practices and proficiencies ( $\mathrm{p}$. 201-214). Belgrave: Editura Fundației Academice Axis and Fédération Internationale des Professeurs de Langues Vivantes.

Liddicoat, A. J. (2005c). Teaching languages for intercultural communication, in $A n$ International Perspective on Language Policies, Practices and Proficiencies (eds D. Cunningham and A. Hatoss),

Editura Fundației Academice Axis and Fédération Internationale des Professeurs de Langues Vivantes, Belgrave, p. 201-214.

Liddicoat, A. J. \& Kohler, M. (2012). Teaching Asian languages from an intercultural perspective: Building bridges for and with students of Indonesian. In X. Song \& K. Cadman (Eds), Bridging transcultural divides: Asian language and culture in global higher education (p. 7399). Adelaide: University of Adelaide Press.
Liddicoat, A.J., \& Scarino, A. (2013). Intercultural language teaching and learning. West Sussex: Wiley-Blackwell

Liddicoat, A.J., Scarino, A., Papademetre, L., \& Kohler, M. (2003). Report on intercultural language learning. Canberra: Commonwealth Department of Education, Science and Training.

Lucas, J. S. (2003). Intercultural communications for international programs: An experientially-based course design. Journal of Research in International Education, 2(3), 301-314.

Moloney, R. \& Harbon, L. (2010). Making Intercultural Language Learning Visible and Assessable. Intercultural Competence Conference, 1, 281- 303.

Otten, M. (2003). Intercultural learning and diversity in higher education. Journal of Studies in International Education, 7(1), 12-26.

Rodliyah, R.T. \& Muniroh, R. D. D. (2012). The importance of incorporating the target culture in English language teaching. [Online]. Available at: http://file.upi.edu/Direktori/FPBS/I UR._PEND._BAHASA_INGGRIS/197 308062002122ROJAB_SITI_RODLIYA H/The_Importance_of_Incorporating the_Target_Culture_in_Englis.pdf.

Sukarno. (2012). Integrating local cultures in teaching English as a foreign language for character building. [Online]. Available at: http://lppmp.uny.ac.id/sites/ lppmp.uny.ac.id/files/8Sukarno $\% 20 \mathrm{~F}$ BS_pdf.

Tantri, N.R. (2013). English as a global language phenomenon and the need of cultural conceptualizations awareness in Indonesian ELT. International Refereed \& Indexed Journal of English Language $\mathcal{E}$ Translation Studies, 1(1), 37-49. 